\title{
The Mapping of Learning Needs in the Development of Religious-Values Based Training Model to Build Youth Character
}

\author{
Jajat S Ardiwinata, Viena Rusmiati Hasanah, Elih Sudiapermana, Syifaa Nuur Faatihah \\ Department of Nonformal Education \\ Universitas Pendidikan Indonesia \\ viena@upi.edu
}

\begin{abstract}
This research concerns the mapping of learning needs in the development of religious-values based training model to build youth character. The data were collected by means of interview and focused-group discussion involving a number of youths and figures of education, of community, and of religion. The results showed that; (1) condition of social economy of the youth's families can be categorized middle to low. (2) condition of social and culture environment is not conducive to build positive character of the youths. (3) figures of community have high expectations on the foster of youths through routine religious fostering program, balanced with sports and other positive activities in building character and independence.
\end{abstract}

Keywords: Mapping of learning needs, religious- values based training, youth character, community figures

\section{INTRODUCTION}

Preparing youth to be a man of character and at the same time equipping them with sense of leadership indicates the building process of an individual to have a strong character to become a role model for those who are led by him. Law Number 40 Year 2009 regarding youth states that "Youths are Indonesian citizens that are in significant period for growth and development and are from 16 to 30 years in age". Projection of Statistical Bureau Center declares that in 2015, youth population was 62.4 million. It indicates that on average, youth population is 25 percent of the total number of Indonesian citizens.

Various social problems occur among youths such as the use of narcotics and other illegal drugs, gang fights among school children, pornography, rape, seizure, fraud, abortion, gambling and so on. Those problems have been around with and yet have no settlements. Final Report of National Survey on the Development of Misused Drugs Budget Year 2014 states that number of misused drugs was approximately 3.8 to 4.1 million people and those are current users with 10-59 in ages [1]

Model of religious-values based training, developed in the meantime, can be used as an alternative solution to build youth character and to overcome youth problems. Training needs and learning needs analyses become one of the steps in the development of this training model. This research is aimed at finding out the mapping of learning needs of youth to develop religious-values based training.

\section{LITERATURE REVIEW}

\section{A. Definition and Aim of Training}

Training refers to a process of empowerment and learning, meaning that an individual (a community member) should learn something (materials) to improve his abilities, skills, and characters in his works and daily life to support economy (income). The training aims to develop communities' skills and abilities to identify their own potentials in general as the basis for the development of entrepreneur [2]

\section{B. Definition of Training Needs Identification}

Training needs identification is defined as an activity to identify, recognize, and arrange priority to plan steps for future use of training. By doing needs identification, it is expected that the aim of the training can be attained. Learning needs of future learners in certain scopes cover the needs of three areas, namely organizational, occupational and individual needs [3]

\section{METHODOLOGY}

This research used qualitative approach and method. The data were collected by means of interview, observation, and focused-group discussion techniques. The research involved 30 youths and 5 figures of communities in Bandung, Indonesia.

\section{RESULTS AND DISCUSSIONS}

\section{A. Condition of Social and Economy}

The research found that condition of social and economy of youth's family in the research setting was categorized low. Viewed from education level, most parents education were only senior high school and junior high school graduates. Low level of education tends to reflect low social and economy conditions. Education is an effort done by an individual or groups to improve their lives, particularly in their mental aspects [4]. Low education level results in limited social and economy conditions since jobs they do will depend on their abilities. Education is inclined to outcome or impacts influencing on three aspects involving firstly, the change of life 
prosperity, marked by job occupancy, the increase of income, health and looks, secondly, the increase of participation in social activities and community development in their own neighborhoods in the forms of thoughts, powers, possessions, and money and thirdly, the process of making other learn on the learning results they have already possessed [5]. In this case, therefore, it can be concluded that the success of process of education influence on three aspects of those outcomes.

Most communities in the area were laborer and housewives. Social economy condition is also influenced by consumption and expenses, including the income, household composition and environment demands. The research found that income of youths' parents in the research setting were mostly less than Rp500.000,00/ month, indicating that their incomes are in low category as can also be seen from the following categorization of income: high level income is above Rp3.000.000,00/ month, mid level income is from Rp1000.000 to Rp3.000.000,00/ month while low level income is under Rp1.000.000,00/month.

\section{B. Condition of Environment, Social and Culture}

The research area is a place, famous for youth notorious actions such as drinking, smoking, and using drugs. Head of Administrative Unit of area, Drs. Atang Rachman, in this case, commented that "Condition of this area is full of many crime cases. Once there was jabbing, the other time was crimes done by some citizens of the area and thus, a special fostering program and development are needed for the area".

"Religious-values based education and training is expected to equip them to be men of character, leading to positive youth character building, being able to distinguish good and bad. Moreover, the reality shows that children and teenagers have involved themselves with bad behavior such as gang fight among school children, immoral actions, illegal drugs, pornography and pornoaction and etc."

The results of observation and interview showed that the area was lack of open areas such as sports and recreational areas for children and youth to develop their potentials. It was attributed to the densely populated areas. Furthermore, mosques built in the area have not optimally benefited its citizens due to lack support from the citizens themselves.

\section{Expectation of Figures of community}

The research found that there were three community members in the research setting that are influential in certain areas including education, religion and youth related issues. Figure of community in an area is like a well respected leader for the area, despite the fact that he may have limited knowledge. However, he is acknowledged by his people as a person who is sensitive to many problems in his area. These figures can influence attitudes and behaviors of citizens to act in a certain way. Three figures of community in the research setting have similar characteristics such as having high social and economy statuses, being more innovative in relation to activities conducted for societies in the neighborhood, having big empathy for problems occurred in the neighborhood as well as high participation to situation and condition of the neighborhood [6].

\section{The results of focused-group discussion showed several statements viewed below.}

Head of community in the area stated that "learning needs for youths in the area are inclined to character education, learning manners, for example learning how to speak polite based on context and situation. The area used to have manners fostering program for the youths in the area".

Mrs. Santi (Figure of Education) declared that "I have the same intentions; to save children of the area because their brothers and sisters have involved with bad actions such as using drugs, smoking and other bad doings. We also pay attention to their mothers by giving them training and fostering, since the parents are sometimes spoiled themselves in front of TV watching dramas rather than looking for their children in internet cafe. Therefore, in this case, there should be synchronization between the needs of children and parents".

Mr. Yusuf (Figure of Youths) stated that "Problems related to religious activity, and youth positive activity occur because the neighborhood is not really conducive. For example, there is two sides of places for studying Islam at the meantime, while it can actually be focused in one mosque. So my wish regarding this problem is that using mosque as the center for studying Islam so that there will be no dispute between different sides. Further, in terms of education, I really hope that researcher can assist us in providing additional lessons especially to children by teaching them Maths and English".

\section{CONCLUSION}

Condition of social, economy, environment, and culture in the place where the youths are staying, roles and supports of the community figures, and their expectations have become good input for the research to map out learning needs for the youths, particularly, in the development of religious-values based training model to build youth character.

The results of observation, interview and discussion done with community figures, youths, and housewives results in the mapping of social economy condition, social and culture condition and other related problems with religious fostering program, family and youth that are in need of supports with consistency in activities, with structures and infrastructures to facilitate sports, arts and cultural and religious activities. Those positive activities are expected to reduce and even eliminate negative activities that have become the problems of the research settings.

The mapping of learning needs results in recommendation stating that all religious figures as well as community figures need advocacy from the right parties so that they can be motivated and further be able to build better citizens.

\section{REFERENCES}

[1] Kompasiana, 2015

[2] Kamil, Mustofa, Model Pendidikan dan Pelatihan (Konsep dan Aplikasi), Penerbit Alfabeta Bandung, 2012

[3] Erasmus et al, 2000; Goldstein, 1993; Van Dyk et al, 1997

[4] Hasbullah, Dasar-dasar Ilmu Pendidikan, Penerbit PT. Grafindo, Jakarta, 2005 
[5] Sudjana, Djudju, Manajemen Program Pendidikan: untuk Pendidikan Nonformal dan Pengembangan Sumber Daya Manusia, Penerbit Al Falah, Bandung, 2010

[6] Nurudin, Komunikasi Massa, Pustaka Pelajar, Jogyakarta, 2004 